\title{
Peningkatan Kualitas Jasa Fasilitas Kesehatan dengan Integrasi Metode IPA dan KANO
}

\section{Shanty Kusuma Dewi*, Ananda Rizky Calfintry Putri, Bagus Arif Dwi Winarko \\ Program Studi Teknik Industri, Fakultas Teknik, Universitas Muhammadiyah Malang, Jl. Raya Tlogomas No. 246 Malang,} Jawa timur, 65144, Indonesia

\section{ARTICLE INFORMATION}

Article history:

Received: November 02, 2018

Revised: November 30, 2018

Accepted: December 07, 2018

\section{Kata Kunci:}

Metode IPA

Metode Kano

Pelayanan Jasa

\section{A B S T R A K}

Perkembangan fasilitas pelayanan kesehatan dan meningkatnya pola pikir masyarakat akan kesehatan, menyebabkan masyarakat lebih kritis dalam menentukan pilihan dalam memenuhi kebutuhan akan pelayanan kesehatan untuk memperoleh hasil yang maksimal. Meningkatnya perkembangan fasilitas kesehatan penuntut peyedia layanan untuk memberikan pelayanan yang terbaik untuk bisa tetap bersaing dan terus berkembang. Tujuan dari penelitian ini adalah untuk meningkatkan kualitas pelayanan yang diberikan pada suatu fasilitas kesehatan. Untuk itu dilakukan analisa tingkat pelayanan jasa yang diberikan dengan menggunakan integrasi metode IPA dan metode Kano. integrasi IPA dan KANO dapat mengetahui atribut layanan mana yang harus ditingkatkan serta atribut yang harus dipertahankan. Dari analisa yang dilakukan didapatkan hasil 14 atribut yang harus tetap dipertahankan dan 13 atribut yang harus ditingkatkan.

\section{A B S T R A C T}

Health services facilities development and people mindset about health make people more critical in making decision to their needs of health services. The increased of the health fasilities made the owner to provide the best service, so they can be able to compete and growth. The purpose of this study is to improve the service quality of health service facility. The objective of this research is to improve the level of services quality on the health service. Integration of the IPA method and the Kano are used to determine which attributes should be improve to meet customer satisfaction. The result from this method are 14 attributes on the position keep up the good work and 13 attributes must be improved.

\section{PENDAHULUAN}

Peningkatan kualitas hidup dan pola pikir masyarakat, menyebabkan masyarakat mulai kritis dalam menentukan sarana kesehatan untuk memperoleh pelayanan kesehatan yang maksimal. Sarana kesehatan yang dimaksud disini adalah sarana kesehatan yang disediakan pemerintah seperti rumah sakit daerah, atau yang disediakan pihak swasta seperti klinik atau rumah sakit mandiri. Semakin banyak penyedia sarana kesehatan yang bersaing untuk mendapatkan bagian yang lebih besar di pasar [1] dalam memahami dan memenuhi kebutuhan serta harapan pelanggan yang berhubungan dengan kualitas pelayanan, kepuasan pelanggan, dan biaya medis [2].

Sebagai salah satu kota yang cukup besar di Jawa Timur, fasilitas kesehatan di Kota Ponorogo dapat dikatakan cukup berkembang. Hal ini dapat dilihat dari jumlah klinik kesehatan yang dibuka berjumlah sekitar 21 buah. Dengan persentase kunjungan rawat jalan yang meningkat dari tahun 2015 sebesar $42,8 \%$ menjadi $47,8 \%$ pada tahun 2016. Akan tetapi kunjungan ke klinik kesehatan hanya $5 \%$ dari total kunjungan rawat jalan dari semua fasilitas kesehatan yang tersedia. 
Pelayanan yang baik kepada pelanggan merupakan salah satu faktor untuk meningkatkan kepuasan pelanggan dan kesetiaan pelanggan. Pelayanan merupakan faktor utama didalam kegiatan jasa. Jasa adalah suatu kegiatan yang mempunyai beberapa unsur ketidakberwujudan yang diberikan suatu pihak ke pihak lainnya yang tidak menghasilkan transfer kepemilikan [3] atau memberikan manfaat bagi pihak terkait [4]. Sedangkan pelayanan adalah upaya untuk membantu menyiapkan, menyediakan, atau mengurus keperluan orang lain [5]. Kualitas pelayanan merupakan dasar bagi pemasaran jasa, karena inti produk yang dipasarkan adalah suatu kinerja (yang berkualitas), dan kinerjalah yang dibeli oleh pelanggan, sehingga kualitas kinerja pelayanan merupakan dasar bagi pemasaran jasa [6].

Beberapa penelitian terdahulu telah dilakukan untuk meningkatkan kualitas layanan. Salah satu metode yang digunakan adalah dengan integrasi metode IPA dan KANO pada perusahaan air minum [7], bengkel [8], maupun pada bidang pendidikan [9]-[11], sedangkan pada penelitian ini yang menjadi obyek penelitian adalah fasilitas kesehatan yaitu klinik kesehatan. Tujuan yang ingin dicapai dalam penelitian ini yaitu mengetahui tingkat kepuasan pasien terhadap pelayanan yang diberikan oleh suatu fasilitas kesehatan dan prioritas layanan yang perlu ditingkatkan berdasarkan integrasi IPA dan KANO.

\section{METODE PENELITIAN}

Objek dari penelitian ini adalah salah satu klinik kesehatan swasta yang berada di kota Ponorogo, Jawa Timur. Kepuasan atau ketidakpuasan merupakan respon pelanggan terhadap kualitas pelayanan yag dirasakan antara harapan dan kinerja pelayanan yang dirasakan. Konsep kepuasan pelanggan untuk memenuhi kebutuhan pelanggan dapat dilihat pada gambar 1 .

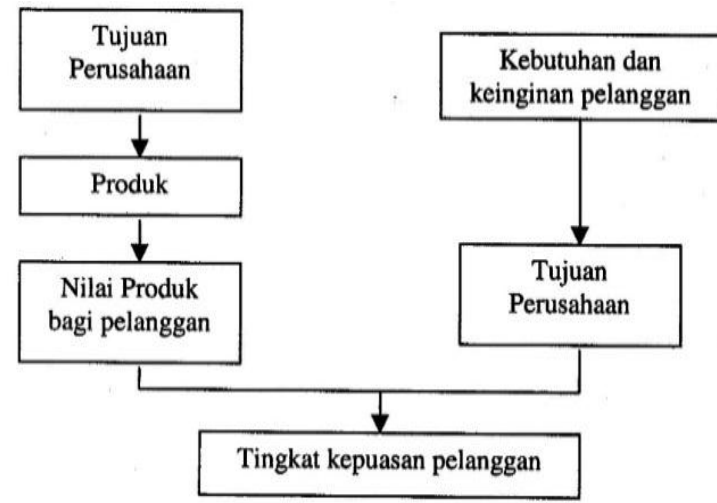

Gambar 1. Konsep kepuasan pelanggan [3]
Pada penelitian ini terdiri dari beberapa tahapan yaitu mulai dari penyusunan kuesioner, uji validitas dan reabiitas kuesioner, perhitungan skor untuk IPA dan KANO serta integrasi IPA dan KANO untuk mendapatkan prioritas atribut layanan.

\section{Tahap Penyusunan Kuesioner}

Penyusunan Kuesioner didapatkan dari hasil wawancara untuk mempresentasikan seberapa besar keinginan pelanggan tersebut. Kuisioner disebar kepada pelanggan yang mendatangi klinik. Dalam penyusunan kuisioner terdapat 5 karakteristik kualitas jasa yang dibahas, yaitu Tangibles, Realibility, Responsive, Assuremce, dan Emphaty

\section{Tahap Uji Validasi dan Reliabilitas}

Uji validitas dan reliabilitas digunakan untuk mengetahui kuesioner sudah valid dan reliabel sebelum dilakukan pengolahan data. Uji ini dilakukan terhadap 30 hasil jawaban kuisioner yang telah dibagikan. Uji validitas dan uji reliabilitas dilakukan dengan menggunakan software SPSS.

\section{Tahap Integrasi IPA dan Kano}

Pada tahapan ini dilakukan pengelompokan dari hasil kuesioner dalam metode IPA lalu dilanjutkan dengan metode Kano. Dari hasil pengelompokan keduanya kemudian diintegrasi menjadi satu untuk mengetahui layanan apakah yang menjadi prioritas.

\section{Metode Kano}

Metode Kano adalah suatu metode yang secara logis melakukan penilaian perasaan konsumen mengenai atribut produk/layanan tertentu berdasarkan seberapa baik pelanggan menerima pelayanan yang dirasakannya [12]. Hubungan antara kepuasan pelanggan dan fasilitas pelayanan sesuai diagram Kano pada gambar 2.

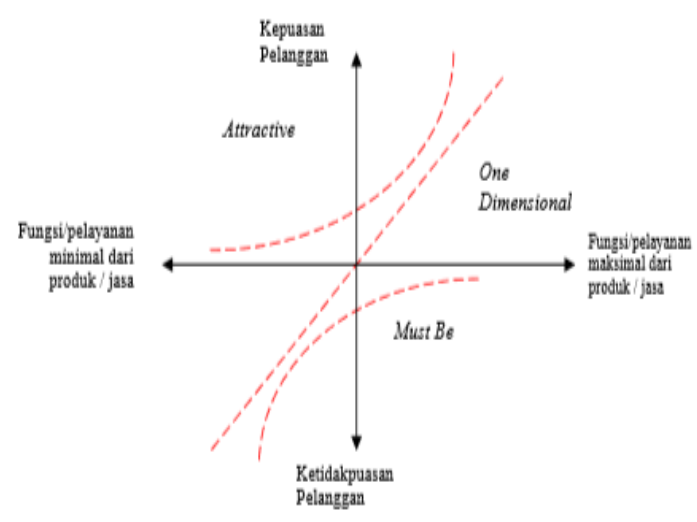

Gambar 2. Grafik Diagram KANO [5], [7] 
Atribut-atribut layanan dapat dibedakan menjadi beberapa kategori yaitu 11 :

a. Must Be atau Basic Needs. (M),

Pada kategori keharusan (must be) atau kebutuhan dasar (basic needs), pelanggan menerima begitu saja ketika terpenuhi. Namun, jika produk atau layanan tidak cukup memenuhi kebutuhan dasar, pelanggan akan menjadi sangat tidak puas. Misalnya, meskipun memiliki pelayan yang tidak ramah menyebabkan ketidakpuasan pelanggan, memiliki pelayanan yang ramah tidak meningkatkan tingkat kepuasan pelanggan karena kehadiran asisten penjualan yang ramah adalah kebutuhan dasar [13].

\section{b. One Dimensional atau Performance Needs} (O),

Kategori one dimensional atau performance needs. Tingkat kepuasan pelanggan berhubungan linear dengan kinerja atribut, sehingga semakin tinggi kualitas layanan yang dirasakan, semakin tinggi kepuasan pelanggan dan sebaliknya [14], [15].

c. Attractive atau Excitement Needs (A),

Pada kategori attractive atau excitement needs, tingkat kepuasan pelanggan yang tinggi saat terpenuhi, tetapi tidak menimbulkan ketidakpuasan ketika tidak dipenuhi karena tidak diharapkan oleh pelanggan, yang mungkin tidak mengetahui fitur produk tersebut [16].

d. Indifferent (I),

Merupakan atribut pelengkap yang kurang diperhatikan pelanggan. Atribut ini kurang mempunyai pengaruh terhadap kepuasan pelanggan.

e. Reverse (R),

Merupakan atribut yang tidak diinginkan pelanggan. Pelanggan merasa puas jika atribut ini tidak ada.

f. Questionable Results (Q),

Respon yang diberikan pelanggan akan atribut tertentu dapat menimbulkan kontradiksi yang masih bisa dipertanyakan.

Cara perhitungan Model Kano dapat menggunakan tabel evaluasi Kano seperti gambar 3.

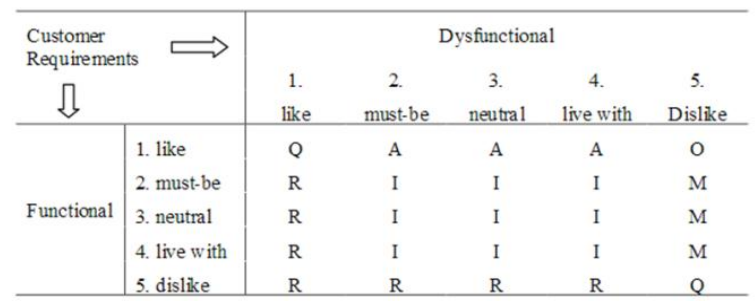

Gambar 4. Tabulasi evaluasi kano [7]
Dari masing-masing pertanyaan yang diajukan kepada responden, selanjutnya penentuan jumlah kategori Kano antara lain [17]:

- Jika $(O+A+M)>(I+R+Q)$ maka grade dari yang paling maksimum dari $(\mathrm{O}, \mathrm{A}, \mathrm{M})$.

- Jika $(O+A+M)<(I+R+Q)$ maka grade dari yang paling maksimum dari $(I, R, Q)$.

- Jika $(O+A+M)=(I+R+Q)$ maka grade paling maksimum diantara semua kategori

Dari hasil perhitungan, koefisien kepuasan konsumen dapat dicari dengan rumusan [18]:

1. Tingkat kepuasan

Koefisian tingkat kepuasan berkisar antara 0 sampai dengan 1 , semakin dekat dengan nilai 1 maka semakin mempengaruhi kepuasan konsumen, dan sebaliknya.

$\frac{A+O}{A+O+M+I}$

2. Tingkat ketidak puasan .

Jika nilai semakin mendekati angka -1 maka pengaruh terhadap kekecewaan konsumen semakin kuat, dan sebaliknya.

$-\frac{O+M}{A+O+M+I}$

\section{Metode Importance Performance Analysis (IPA)}

IPA adalah alat bantu yang digunakan untuk memetakan kinerja/pelayanan yang diberikan dengan harapan yang diinginkan pelanggan [19]. Hasil pemetaan ini akan terbagi kedalam empat kuadran yang memiliki arti dan penanganan yang berbeda-beda. Dalam mengukur tingkat kesesuaian antara persepsi dan harapan pelanggan menggunakan rumus sebagai berikut [20] :

$T k i=\frac{\sum X i}{\sum Y i} \times 100 \%$

dimana :

Tki : Tingkat kesesuaian responden.

Xi : Skor rata-rata penilaian kinerja perusahaan.

Yi : Skor rata-rata penilaian harapan responden.

Setelah pengukuran tingkat kesesuaian, lalu membuat peta posisi importance - performance yang dibatasi oleh 2 buah garis berpotongan tegak lurus pada titik-titik :

$X=\frac{\sum_{i=1}^{N} X i}{k}$ 
$Y=\frac{\sum_{i=1}^{N} Y i}{k}$

dimana :

X : Rata-rata dari rata-rata skor tingkat kinerja seluruh atribut.

Y : : Rata-rata dari rata-rata skor tingkat harapan seluruh atribut.

$\mathrm{K} \quad$ : Banyaknya atribut yang mempengaruhi kepuasan.

Selanjutnya sumbu mendatar (X) akan diisi oleh skor tingkat kinerja, sedangkan sumbu tegak (Y) akan diisi oleh skor tingkat harapan. Dalam penyederhanaan rumus, maka untuk setiap atribut digunakan.

$X=\frac{\sum X i}{n}$

$Y=\frac{\sum Y i}{n}$

dimana :

X : Skor rata-rata persepsi / performance.

Y : Skor rata-rata harapan / importance.

$\mathrm{N} \quad$ : Jumlah responden.

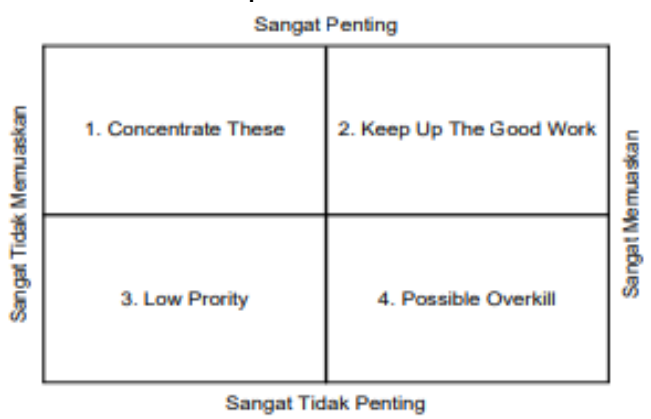

Gambar 5. Matriks IPA [20]

Pembagian kuadran dalam ImportancePerformance Analysis dapat dilihat sebagai berikut :

1. Kuadran 1 (Concentrate These) adalah wilayah yang memuat faktor-faktor yang dianggap penting oleh pelanggan, tetapi tingkat kepuasan yang diperoleh masih rendah sehingga variabel yang masuk dalam kuadran ini memerlukan prioritas yang harus ditingkatkan.

2. Kuadran 2 (Keep Up The Good Work) adalah wilayah yang memuat faktor-faktor yang dianggap penting oleh pelanggan, dan sudah sesuai dengan yang dirasakan pelanggan sehingga tingkat pelayanan harus tetap dipertahankan.

3. Kuadran 3 (Low Priority) adalah wilayah yang memuat faktor-faktor yang dianggap kurang penting oleh pelanggan dan pada kenyatannya kinerjanya tidak terlalu istimewa.
4. Kuadran 4 (Possible Overkill) adalah kuadran yang mendapat pelayanan yang berlebihan dan kurang dianggap penting oleh pelanggan. Variabel dalam kuadran ini dapat diturunkan pelayanannnya untuk menghemat biaya.

\section{Integrasi Metode IPA dan Kano}

Setelah pengelompokan berdasarkan metode IPA dan KANO selanjutnya adalah mengintegrasikan atribut tersebut. Model integrasi yang dipakai adalah model yang diusulkan oleh16 4[21]. Dari integrasi ini dapat diketahui atribut layanan mana yang harus ditingkatkan serta atribut mana yang harus dipertahankan. Model integrasi pada gambar 4

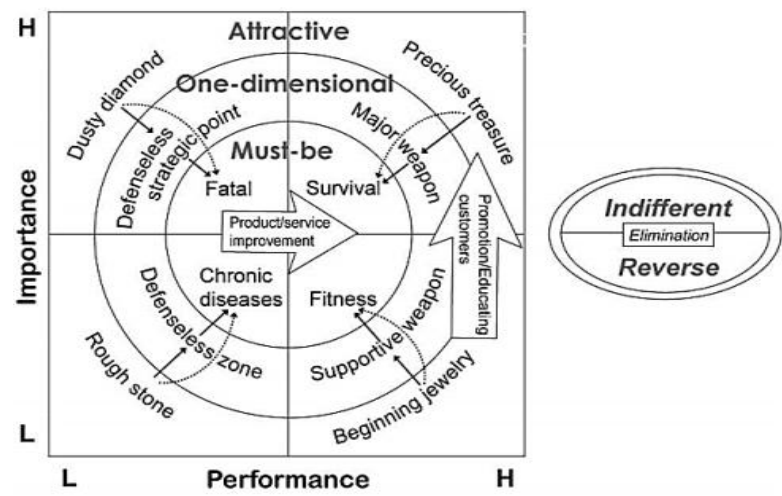

Gambar 4. Model Integrasi IPA-Kano [11]

\section{HASIL DAN PEMBAHASAN}

\section{Penentuan dan Pengambilan sampel}

Penentuan jumlah sampel dengan menggunakan persamaan Bernaulli. Perhitungan sampel untuk validasi dan reabilitas data menggunakan sistem distribusi normal yaitu 30 responden. Deskripsi karakteristik responden sebanyak 70 orang. Dengan persentase perempuan sebesar 52,85\% dan laki-laki sebesar 47,18\%. Mayoritas responden adalah berumur lebih dari 36 tahun sebanyak $28,59 \%$ dan yang paling sedikit adalah yang berumur 17 sampai 21 tahun yaitu $12,85 \%$

\section{Uji Validitas}

Uji Validasi untuk menguji apakah hasil dari kuisioner yang telah disebarkan dinyatakan valid atau tidak. Kuisioner dikatakan valid apabila pertanyaan yang diajukan bisa mengungkapkan hal yang akan diteliti ( $r$ hitung $\geq r$ tabel)8. Jumlah sampel yang digunakan adalah 30 dan diketahui nilai $r$ tabel adalah 0,361. Pada gambar 5 . di bawah diketahui atribut dinyatakan valid, selanjutnya uji Reliabilitas. 


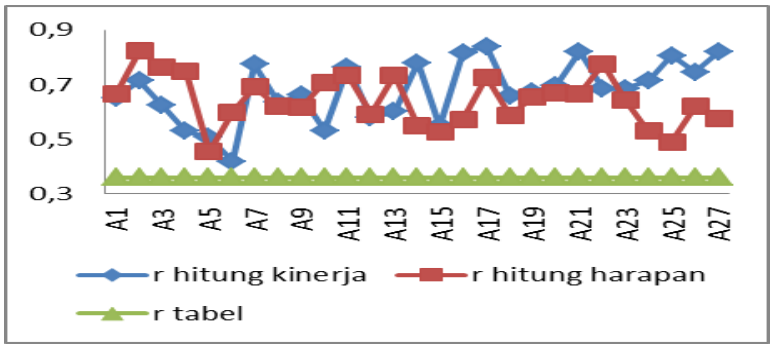

Gambar 5. Grafik hasil rekapan Uji Validasi kuisioner IPA

\section{Uji Reliabilitas}

Metode yang digunakan dalam uji reabilitas adalah metode Cronbach Alpha. Cronbach's Alpha digunakan untuk menguji konsistensi internal dari data yang merupakan sebuah ukuran keandalan yang memiliki nilai berkisar dari nol sampai satu.

Tabel 1. Hasil Rekapan Uji Validasi Kuisioner IPA Kinerja

\begin{tabular}{ll}
\hline \multicolumn{2}{c}{ Reliability Statistics } \\
\hline Cronbach's Alpha $\quad \mathrm{N}$ of Items \\
.756 & 28 \\
\hline
\end{tabular}

Tabel 2. Hasil Rekapan Uji Validasi Kuisioner IPA Kepentingan

\begin{tabular}{ll}
\hline Reliability Statistics & \\
\hline Cronbach's Alpha & N of Items \\
0.754 & 28 \\
\hline
\end{tabular}

Berdasarkan tabel 1 dan 2 hasil uji reliabilitas didapatkan nilai $0.756>0.7$ (kinerja), $0.754>$ 0.7(kepentingan) untuk kuisioner IPA, yang berarti kuesioner tersebut reliabel. Setelah dilakukan pengujian validitas dan reliabilitas dengan hasil pernyataan valid dan reliabel untuk keseluruhan atribut maka selanjutnya dapat dilakukan penyebaran kuisioner sebanyak sempel yang telah ditentukan.

\section{Metode Importance Performance Analysis (IPA)}

Perhitungan rata-rata nilai kepentingan dan nilai kinerja dari setiap atribut dilakukan untuk mempermudah mengolah data pada metode IPA. Total nilai tingkat kepentingan dan kinerja dihitung dengan mengalikan jawaban responden dengan skala Likert. Hasil perhitungan nilai total nilai kinerja pelayanan tiap atribut sesuai dengan tabel 3.

Selanjutnya pengolahan data untuk nilai rata-rata dari tiap atribut. Berikut ini contoh perhitungan rata - rata tingkat kinerja kebersihan dan kenyamanan ruang tunggu :

Rata-rata kinerja atribut $1=$ $\frac{\text { Total nilai pelayanan atribut }}{\text { jumlah responden }}=\frac{254}{70}=3,629$

Hasil perhitungan nilai rata - rata tingkat kinerja dan kepentingan untuk setiap atribut dapat dilihat pada tabel 4

Tabel 3. Hasil Perhitungan Total Nilai Kinerja dan Kepentingan

\begin{tabular}{|c|c|c|c|c|c|c|c|c|c|c|c|c|c|}
\hline \multirow{2}{*}{ No. } & \multirow{2}{*}{ Atribut } & \multicolumn{6}{|c|}{ Kinerja } & \multicolumn{6}{|c|}{ Kepentingan } \\
\hline & & SS & $S$ & $\mathrm{~N}$ & TS & STS & Total & SS & $S$ & $\mathrm{~N}$ & TS & STS & Tota \\
\hline \multicolumn{14}{|c|}{ A. Tangible } \\
\hline 1 & $\begin{array}{l}\text { Tersedianya tempat parkir yang } \\
\text { luas }\end{array}$ & 85 & 68 & 87 & 14 & 0 & 254 & 210 & 84 & 18 & 2 & 0 & 314 \\
\hline 2 & $\begin{array}{l}\text { Kenyamanan tempat duduk } \\
\text { pada ruang tunggu }\end{array}$ & 100 & 132 & 51 & 0 & 0 & 283 & 225 & 76 & 18 & 0 & 0 & 319 \\
\hline 3 & Tersedianya tempat sampah & 185 & 76 & 42 & 0 & 0 & 303 & 195 & 76 & 24 & 8 & 0 & 303 \\
\hline 4 & Tersedianya toilet yang bersih & 95 & 124 & 51 & 6 & 0 & 276 & 205 & 76 & 27 & 2 & 0 & 310 \\
\hline 5 & Tersedianya fasilitas televisi & 105 & 140 & 27 & 10 & 0 & 282 & 195 & 68 & 36 & 4 & 0 & 303 \\
\hline 6 & Terdapat fasilitas apotek & 85 & 124 & 57 & 6 & 0 & 272 & 105 & 152 & 33 & 0 & 0 & 290 \\
\hline 7 & $\begin{array}{l}\text { Lingkungan klinik yang nyaman } \\
\text { dan rapi }\end{array}$ & 105 & 148 & 30 & 4 & 0 & 287 & 100 & 164 & 27 & 0 & 0 & 291 \\
\hline 8 & $\begin{array}{l}\text { Kelengkapan sarana hiburan } \\
\text { pada area ruang tunggu }\end{array}$ & 65 & 104 & 51 & 18 & 5 & 243 & 85 & 176 & 21 & 4 & 0 & 286 \\
\hline 9 & $\begin{array}{l}\text { Dokter dan karyawan selalu } \\
\text { berpakaian rapi (menggunakan } \\
\text { seragam kerja) }\end{array}$ & 185 & 72 & 39 & 4 & 0 & 300 & 215 & 60 & 30 & 4 & 0 & 309 \\
\hline
\end{tabular}


Tabel 3. Hasil Perhitungan Total Nilai Kinerja dan Kepentingan (lanjutan)

\begin{tabular}{|c|c|c|c|c|c|c|c|c|c|c|c|c|c|}
\hline \multirow{2}{*}{ No. } & \multirow{2}{*}{ Atribut } & \multicolumn{6}{|c|}{ Kinerja } & \multicolumn{6}{|c|}{ Kepentingan } \\
\hline & & SS & $\mathrm{S}$ & $\mathrm{N}$ & TS & STS & Total & SS & S & $\mathrm{N}$ & TS & STS & Total \\
\hline \multicolumn{14}{|c|}{ B. Reliability } \\
\hline 10 & $\begin{array}{l}\text { Pelayanan dokter dijalankan } \\
\text { sesuai dengan jadwal }\end{array}$ & 95 & 136 & 27 & 14 & 1 & 273 & 90 & 168 & 24 & 4 & 0 & 286 \\
\hline 11 & Dokter melayani dengan ramah & 210 & 64 & 33 & 2 & 0 & 309 & 215 & 72 & 27 & 0 & 0 & 314 \\
\hline 12 & $\begin{array}{l}\text { Lokasi Klinik dapat dijangkau } \\
\text { para pasien }\end{array}$ & 85 & 152 & 39 & 4 & 0 & 280 & 70 & 180 & 33 & 0 & 0 & 283 \\
\hline 13 & $\begin{array}{l}\text { Jumlah dokter sebanding } \\
\text { dengan pasien }\end{array}$ & 55 & 72 & 117 & 4 & 0 & 248 & 205 & 72 & 24 & 6 & 0 & 307 \\
\hline 14 & $\begin{array}{l}\text { Harga jasa sesuai dengan } \\
\text { kualitas yang ditawarkan }\end{array}$ & 60 & 164 & 45 & 0 & 2 & 271 & 90 & 172 & 27 & 0 & 0 & 289 \\
\hline \multicolumn{14}{|c|}{ C. Responsiveness } \\
\hline 15 & $\begin{array}{lll}\text { Prosedur } & \text { pendaftaran pasien } \\
\text { cepat dan } & \text { pelayanan } \\
\text { pemeriksaan cepat } & \end{array}$ & 55 & 176 & 45 & 0 & 0 & 276 & 195 & 84 & 24 & 4 & 0 & 307 \\
\hline 16 & $\begin{array}{l}\text { Kesigapan dokter dalam } \\
\text { menanggapi keluhan pasien }\end{array}$ & 85 & 156 & 33 & 6 & 0 & 280 & 200 & 84 & 27 & 0 & 0 & 311 \\
\hline 17 & $\begin{array}{l}\text { Adanya penjelasan mengenai } \\
\text { penyakit yang diderita }\end{array}$ & 95 & 156 & 36 & 0 & 0 & 287 & 205 & 92 & 15 & 2 & 0 & 314 \\
\hline 18 & Pelayanan pengambilan obat & 85 & 140 & 45 & 6 & 0 & 276 & 165 & 124 & 15 & 2 & 0 & 306 \\
\hline \multicolumn{14}{|c|}{ D. Assurance } \\
\hline 19 & $\begin{array}{l}\text { Keamanan kendaraan pada saat } \\
\text { pasien menggunakan jasa } \\
\text { tersebut (parkir kendaraan) }\end{array}$ & 65 & 96 & 96 & 2 & 0 & 259 & 130 & 152 & 12 & 4 & 0 & 298 \\
\hline & $\begin{array}{ll}\begin{array}{l}\text { Kejelasan dan } \\
\text { dokter dalam }\end{array} & \text { keakurantan } \\
\text { memberikan }\end{array}$ & & & & & & & & & & & & \\
\hline 20 & $\begin{array}{l}\text { informasi dan jawaban kepada } \\
\text { pasien terkait dengan penyakit } \\
\text { yang diderita } \\
\text { Dokter maupun karywan selalu }\end{array}$ & 85 & 136 & 51 & 4 & 0 & 276 & 105 & 164 & 18 & 4 & 0 & 291 \\
\hline 21 & $\begin{array}{l}\text { bersikap sopan dan ramah } \\
\text { kepada pasien }\end{array}$ & 95 & 168 & 24 & 2 & 0 & 289 & 215 & 84 & 9 & 6 & 0 & 314 \\
\hline 22 & $\begin{array}{l}\text { Pelayanan medis yang diberikan } \\
\text { dokter dapat diandalkan }\end{array}$ & 65 & 160 & 51 & 0 & 0 & 276 & 160 & 124 & 21 & 0 & 0 & 305 \\
\hline \multicolumn{14}{|c|}{ E. Emphaty } \\
\hline 23 & $\begin{array}{l}\text { Tersedianya kotak P3K untuk } \\
\text { kebutuhan pasien } \\
\text { Kemudahan pasien dalam }\end{array}$ & 85 & 156 & 42 & 0 & 0 & 283 & 145 & 152 & 9 & 0 & 0 & 306 \\
\hline 24 & $\begin{array}{l}\text { menghubungi petugas maupun } \\
\text { dokter } \\
\text { Dokter memberikan perhatian }\end{array}$ & 75 & 164 & 42 & 0 & 0 & 281 & 130 & 152 & 18 & 0 & 0 & 300 \\
\hline 25 & $\begin{array}{l}\text { yang sama kepada semua } \\
\text { pasien }\end{array}$ & 80 & 168 & 36 & 0 & 0 & 284 & 115 & 156 & 24 & 0 & 0 & 295 \\
\hline 26 & $\begin{array}{l}\text { Dokter bersedia mendengarkan } \\
\text { keluhan pasiennya }\end{array}$ & 105 & 152 & 33 & 0 & 0 & 290 & 115 & 160 & 21 & 0 & 0 & 296 \\
\hline 27 & $\begin{array}{l}\text { Dokter dan karyawan bersedia } \\
\text { menerima saran dari pasien dan } \\
\text { keluarga }\end{array}$ & 75 & 88 & 96 & 2 & 0 & 261 & 195 & 104 & 12 & 2 & 0 & 313 \\
\hline
\end{tabular}


Tabel 4. Hasil Perhitungan Rata-rata Nilai Kepentingan dan Kinerja

\begin{tabular}{cccc}
\hline No. & Atribut & Rata-rata Kinerja $(\mathrm{X})$ & Rata-rata Kepentingan $(\mathrm{Y})$ \\
\hline 1 & A1 & 3.629 & 4.486 \\
2 & A2 & 4.043 & 4.557 \\
3 & A3 & 4.329 & 4.329 \\
4 & A4 & 3.943 & 4.429 \\
5 & A5 & 4.029 & 4.329 \\
6 & A6 & 3.886 & 4.143 \\
7 & A7 & 4.100 & 4.157 \\
8 & A8 & 3.471 & 4.086 \\
9 & A9 & 4.286 & 4.414 \\
10 & A10 & 3.900 & 4.086 \\
11 & A11 & 4.414 & 4.486 \\
12 & A12 & 4.000 & 4.043 \\
13 & A13 & 3.543 & 4.386 \\
14 & A14 & 3.871 & 4.129 \\
15 & A15 & 3.943 & 4.386 \\
16 & A16 & 4.000 & 4.443 \\
17 & A17 & 4.100 & 4.486 \\
18 & A18 & 3.943 & 4.371 \\
19 & A19 & 3.700 & 4.257 \\
20 & A20 & 3.943 & 4.157 \\
21 & A21 & 4.129 & 4.486 \\
22 & A22 & 3.943 & 4.357 \\
23 & A23 & 4.043 & 4.371 \\
24 & A24 & 4.014 & 4.286 \\
25 & A25 & 4.057 & 4.214 \\
26 & A26 & 4.143 & 4.229 \\
27 & A27 & 3.729 & 4.471 \\
\hline & Jumlah & 107.129 & 4.317 \\
\hline & Rata-rata & 3.968 & \\
& & & \\
19 & & \\
\hline
\end{tabular}

Peta pada gambar 6. didapatkan dengan memetakan atribut - atribut pelayanan dimana koordinatnya ditentukan skor kinerja dan kepentingan pelayanan. Sumbu $X$ ditentukan dari nilai rata - rata atribut kinerja dan sumbu $Y$ dari nilai rata - rata atribut kepentingan layanan. Berikut ini diagram matrik dengan menggunakan software SPSS.

Berdasarkan hasil SPSS pada gambar 6 diketahui :

1. Kuadran 1 : atribut $1,4,13,15,18,22$, dan 27

2. Kuadran 2 : atribut $2,3,5,9,11,16,17,21$, dan 23

3. Kuadran 3 : Atribut $6,8,10,14,19$, dan 20

4. Kuadran 4 : Atribut $7,12,24,25$, dan 26

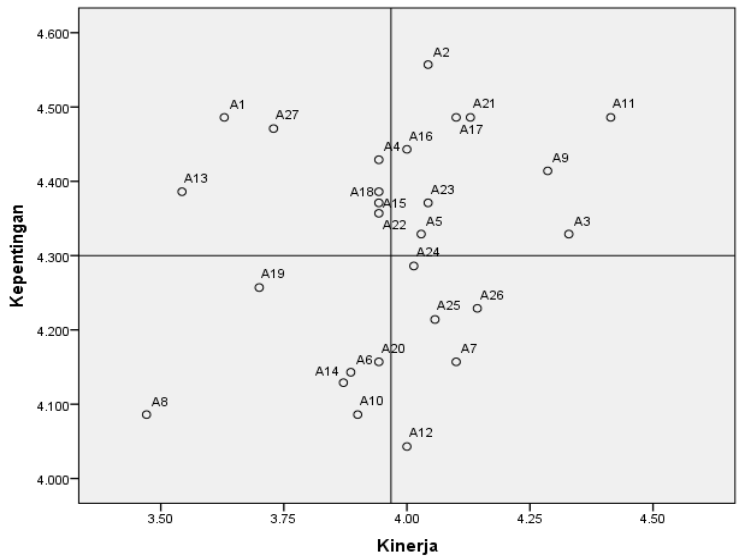

Gambar 6. Hasil ploting atribut 
Metode Kano

Hasil dari pengumpulan data kuisioner kano yang telah ditabulasi berdasarkan kategori Attractive, Must-be, One dimensional, Indifferent, Reverse, dan Questinabel selanjutnya direkapitulasi untuk menentukan kesimpulan kategori kano untuk setiap masing-masing atribut pelayanan pada tabel 5. sebagai berikut :
Tabel 5. rekapitulasi hasil kuisioner kano

\begin{tabular}{ll}
\hline Grade & \multicolumn{1}{c}{ Atribut } \\
\hline \multirow{3}{*}{ A1, A4, A9, A11, A14, A16, A17, } \\
A & A20, A24, A27 \\
& A2, A7, A13, A18, A19, A23, A25 \\
M & A3, A5, A6, A8, A10, A12, A15, \\
\hline
\end{tabular}

\section{Integrasi metode IPA dan Kano}

Pengkategorian atribut - atribut berdasarkan integrasi IPA dan model KANO dapat dilihat pada tabel 6.

Tabel 6. Hasil Rekapitulasi Integrasi IPA - Kano

\begin{tabular}{|c|c|c|c|c|c|}
\hline No. & Atribut & IPA & Kano & IPA-Kano & Keputusan \\
\hline 1 & A1 & 1 & $\mathrm{O}$ & \multirow{3}{*}{ Defenseless } & \multirow{3}{*}{ Peningkatan kinerja 3} \\
\hline 2 & A4 & 1 & $\mathrm{O}$ & & \\
\hline 3 & $\mathrm{~A} 27$ & 1 & $\mathrm{O}$ & & \\
\hline 4 & A9 & 2 & $\mathrm{O}$ & \multirow{4}{*}{ Major Weapon } & \multirow{4}{*}{ Pertahankan Kinerja 3} \\
\hline 5 & A11 & 2 & $\mathrm{O}$ & & \\
\hline 6 & A16 & 2 & O & & \\
\hline 7 & $\mathrm{~A} 17$ & 2 & $\mathrm{O}$ & & \\
\hline 8 & A14 & 3 & $\mathrm{O}$ & \multirow{2}{*}{ Defenseless Zone } & \multirow{2}{*}{ Peningkatan Kinerja 4} \\
\hline 9 & A20 & 3 & $\mathrm{O}$ & & \\
\hline 10 & A24 & 4 & $\mathrm{O}$ & Supportive Weapon & Pertahankan Kinerja 4 \\
\hline 11 & A15 & 1 & M & \multirow{2}{*}{ Fatal } & \multirow{2}{*}{ Peningkatan Kinerja 1} \\
\hline 12 & $\mathrm{~A} 22$ & 1 & $\mathrm{M}$ & & \\
\hline 13 & A3 & 2 & M & \multirow{3}{*}{ Survival } & \multirow{3}{*}{ Pertahankan kinerja 1} \\
\hline 14 & A5 & 2 & M & & \\
\hline 15 & $\mathrm{~A} 21$ & 2 & M & & \\
\hline 16 & A6 & 3 & M & \multirow{3}{*}{ Chronic Diesease } & \multirow{3}{*}{ Peningkatan Kinerja 2} \\
\hline 17 & A8 & 3 & M & & \\
\hline 18 & A10 & 3 & $\mathrm{M}$ & & \\
\hline 19 & $\mathrm{~A} 12$ & 4 & M & \multirow{2}{*}{ Fittness } & \multirow{2}{*}{ Pertahankan Kinerja 2} \\
\hline 20 & A26 & 4 & M & & \\
\hline 21 & A13 & 1 & A & \multirow{2}{*}{ Dusty Diamond } & \multirow{2}{*}{ Peningkatan Kinerja 5} \\
\hline 22 & A18 & 1 & A & & \\
\hline 23 & A2 & 2 & A & \multirow{2}{*}{ Precious Treasure } & \multirow{2}{*}{ Pertahankan kinerj 5} \\
\hline 24 & A23 & 2 & A & & \\
\hline 25 & A19 & 3 & A & Rough Stone & Peningkatan Kinerja 6 \\
\hline 26 & A25 & 4 & $A$ & \multirow{2}{*}{ Begining Jewelry } & \multirow{2}{*}{ Pertahankan Kinerja 6} \\
\hline 27 & A7 & 4 & A & & \\
\hline
\end{tabular}




\section{KESIMPULAN}

Dari hasil peneitian didapatkan 27 atribut layanan pada fasilitas kesehatan. Hasil analisa dengan metode IPA dari 27 atribut layanan tersebut terdapat 7 atribut pada kuadran 1 (concentrate these), 9 atribut pada kuadran (keep up the good work) 6 atribut pada kuadran 3 (low priority) dan 5 atribut pada kuadran 4 (possible overskill). Hasil dari metode KANO terdapat 7 atribut termasuk dalam Attractive, 10 atribut pada Mustbe,dan 10 atribut pada One dimensional. Dari hasil integrasi metode IPA dan KANO didapatkan 14 atribut yang harus dipertahankan kinerjanya agar kepuasan pelanggan tidak turun dan juga 13 atribut yang harus diperbaiki untuk meningkatkan kualitas layanan agar kepuasan pelanggan meningkat.

\section{DAFTAR PUSTAKA}

[1] H. Nadiri and K. Hussain, "Zone of Tolerance for Healthcare Services: A Diagnostic Model of Public and Private Hospital Service Quality," Argumenta Oeconomica, no. 2 (37), pp. 245-280, 2016.

[2] K. W. Kizer, "The emerging imperative for health care quality improvement," Acad. Emerg. Med., vol. 9, no. 11, pp. 10781084, 2002.

[3] A. Payne, The Essence of Service Marketing Pemasaran Jasa. Terjemahan Fandy Tjiptono, Edisi Pertama, Cetakan pertama, Penerbit Andi. Yogyakarta, 2000.

[4] T. Musanto, "Faktor-faktor kepuasan pelanggan dan loyalitas pelanggan: Studi kasus pada CV. Sarana Media Advertising Surabaya," J. Manaj. dan Kewirausahaan, vol. 6, no. 2, pp. 123136, 2005.

[5] A. Aswin, "Studi Tentang Strategi Pelayanan Publik pada Kantor UPTD Dinas Pendapatan Daerah Provinsi Kalimantan Timur di Samarinda," J. Magister IImu Adm. Negara, pp. 1-13, 2015.

[6] T. S. Kaihatu, "Analisa kesenjangan kualitas pelayanan dan kepuasan konsumen pengunjung Plaza Tunjungan Surabaya," J. Manaj. dan Kewirausahaan, vol. 10, no. 1, pp. 66-83, 2008.

[7] N. B. Puspitasari, H. Suliantoro, and L. Kusumawardhani, "Analisis kualitas pelayanan dengan menggunakan integrasi Importance Performance Analysis (IPA) dan model Kano (studi kasus di PT. Perusahaan Air minum Lyonnaise Jaya Jakarta)," J@ ti Undip J. Tek. Ind., vol. 5, no. 3, pp. 185-198, 2010.

[8] S. K. Dewi, "Analisis Kepuasan Pelanggan Dengan Menggunakan Integrasi Importance Performance Analysis dan Model KANO," in Seminar dan Konferensi Nasional IDEC, 2018, pp. $1-11$.

[9] A. F. N. Siti, "Integrasi Metode Importance Performance Analysis dan Model Kano dalam Peningkatan Kualitas Pelayanan (Studi Kasus Perpustakaan Universitas Andalas)," Universitas Andalas, 2016.

[10] H. Handoko, A. R. Matondang, and A. Ishak, "Analisis persepsi jasa pelayanan pendidikan dengan menggunakan model kano dan IPA pada perguruan XYZ," J. Tek. Ind. USU, vol. 2, no. 1, pp. 9-14, 2013.

[11] A. Indrasari, "Integrasi Metode IPA dan Model Kano Dalam Pengembangan Kualitas Pelayanan Perpustakaan," J. IIm. Tek. Ind., vol. 3, no. 1, pp. 45-52, 2017.

[12] J. Mikulić and D. Prebežac, "A critical review of techniques for classifying quality attributes in the Kano model," Manag. Serv. Qual. An Int. J., vol. 21, no. 1, pp. 46-66, 2011.

[13] C. Garibay, H. Gutiérrez, and A. Figueroa, "Evaluation of a digital library by means of quality function deployment (QFD) and the Kano model," J. Acad. Librariansh., vol. 36, no. 2, pp. 125-132, 2010.

[14] R. Redfern and C. L. Davey, "Supply chain market orientation in new product development in the UK: A pilot case study," J. Fash. Mark. Manag. An Int. J., vol. 7, no. 1, pp. 65-77, 2003.

[15] B. Baki, C. Sahin Basfirinci, I. Murat AR, and Z. Cilingir, "An application of integrating SERVQUAL and Kano's model into QFD for logistics services: A case study from Turkey," Asia Pacific J. Mark. Logist., vol. 21, no. 1, pp. 106-126, 2009.

[16] C. Basfirinci and A. Mitra, "A cross cultural investigation of airlines service quality through integration of Servqual and the Kano model," J. Air Transp. Manag., vol. 42, pp. 239-248, 2015.

[17] Y. Ramadhani and P. Suciandani, "Analisis Kepuasan Pengunjung Wisata Dengan Model Kano Berdasarkan Dimensi SERVQUAL," J. Teknol. Technosecientia, vol. 4, no. 1, pp. 113- 
119, 2011.

[18] T. Zhang et al., "Sequencing of allotetraploid cotton (Gossypium hirsutum L. acc. TM-1) provides a resource for fiber improvement," Nat. Biotechnol., vol. 33, no. 5, p. 531, 2015.

[19] M. Yola and D. Budianto, "Analisis kepuasan konsumen terhadap kualitas pelayanan dan harga produk pada supermarket dengan menggunakan metode Importance Performance Analysis (IPA)," J. Optimasi Sist. Ind., vol. 12, no. 12, pp. 301-309, 2013.
[20] R. Nugraha, A. Harsono, and H. Adianto, "Usulan peningkatan kualitas pelayanan jasa pada bengkel ' $x$ ' berdasarkan hasil matrix importance-performance analysis," Reka Integr., vol. 1, no. 3, pp. 221-231, 2013.

[21] Y.-F. Kuo, J.-Y. Chen, and W.-J. Deng, "IPA-Kano model: A new tool for categorising and diagnosing service quality attributes," Total Qual. Manag. Bus. Excell., vol. 23, no. 7-8, pp. 731748, 2012. 